RECOMMENDATIONS

\title{
Prophylaxis of infective endocarditis: French recommendations 2002
}

\author{
N Danchin, X Duval, C Leport
}

Heart 2005;91:715-718. doi: 10.1136/hrt.2003.033183

in nfective endocarditis is a rare but severe disease, the incidence of which seems to have been stable over the past decades. Streptococci are the most frequent causative organisms. In France, infective endocarditis ranges from 25-30 cases/million inhabitants/year (about 1500 cases/year). The profile of patients presenting with infective endocarditis, though, is changing, with an increased proportion of elderly patients and a decrease of endocarditis due to oral streptococci. Valve surgery for endocarditis is performed in about one patient in two with a perioperative mortality that remains high.

Since 1992, the date of the French consensus conference on the prophylaxis of infective endocarditis, new data have been published, requiring an update of its conclusions. These new data feature the following points:

- Endocarditis remains a severe disease

- Bacteraemia causing infective endocarditis is probably more often related to a daily transfer of bacteria from mouth to blood than to occasional oral or dental procedures

- There is no scientific proof of the efficacy, or non-efficacy, of antibiotic prophylaxis

- In France, antibiotic prophylaxis is given to less than one patient in two at risk before oral or dental procedures

- A broad use of antibiotic prophylaxis, supposing that it is totally efficacious, would prevent only a small number of cases in France

- A worrying increase of bacteria with decreased sensitivity to antibiotics has been reported in France.

Consequently the working group suggests:

- to maintain the principle of antibiotic prophylaxis when performing procedures at risk in patients with cardiac conditions at risk, but

- to limit its indications to cases that have the highest ratio of individual benefit to individual and collective risk.

This is the executive summary of the full recommendations, which are available at www.infectiologie.com.

These recommendations, however, cannot substitute for the physician's evaluation of the individual risk in a given patient.

\section{RECOMMENDATION 1: DEFINITION OF GROUPS AT RISK}

Two groups of patients are defined: group A, high risk, for whom the incidence but also the morbidity and mortality of infective endocarditis are high; and group B, with a lower risk (lower incidence and severity) (table 1).

Beside groups A and B, there are many cardiac conditions for which there is no increased risk of infective endocarditis compared with the global population (see full text).

\section{RECOMMENDATION 2: IMPORTANCE OF HYGIENE MEASURES}

General hygiene measures are the most important. They aim at decreasing the risk of bacteraemia. They include oral, dental, and skin hygiene to prevent any rupture of the skin or mucosal barriers, disinfection of wounds, curative antibiotic treatment of infection, and strict compliance with asepsis when performing procedures at risk of infection. A systematic surveillance of the oral and dental state is mandatory at least twice a year for patients with heart diseases.

Any procedure leading to a mucosal or skin wound must be avoided. Thus, skin piercing is strictly contraindicated for patients with cardiac conditions that confer risk. Acupuncture should be avoided. Infusion catheters should be used only when mandatory, especially in patients at risk, with peripheral rather than central catheters and systematic replacement of peripheral catheters every three or four days.

\section{RECOMMENDATION 3: ORAL AND DENTAL CARE}

In group $A$ and $B$ patients, it is recommended that local chlorhexidine based antiseptics be used as mouthwash for 30 seconds before dental procedures and that dental care be provided in as few sessions as possible. If several sessions are required, and if the practitioner uses antibiotic prophylaxis, the sessions must be scheduled at least 10 days apart if possible.

\section{Indications for systemic antibiotic prophylaxis Group A patients}

Using antibiotic prophylaxis according to the rules described below is recommended for non-contraindicated invasive oral or dental procedures (table 2).

Some procedures are contraindicated, such as prostheses on teeth to be pulpectomised, inserting implants, and periodontal surgery. Pulp diseases, periodontal diseases,

Table 1 Cardiac conditions conferring risk of infective endocarditis (IE)

\begin{tabular}{|c|c|}
\hline $\begin{array}{l}\text { Group A: cardiac conditions } \\
\text { conferring high risk of IE }\end{array}$ & $\begin{array}{l}\text { Group B: cardiac conditions } \\
\text { conferring lower risk of IE }\end{array}$ \\
\hline $\begin{array}{l}\text { Valvar prostheses (mechanical, } \\
\text { homograft, or bioprostheses) } \\
\text { - Non-operated cyanotic } \\
\text { congenital heart disease and } \\
\text { pulmonary-systemic shunts } \\
\text { History of IE }\end{array}$ & $\begin{array}{l}\text { Valvar diseases: aortic } \\
\text { insufficiency, mitral } \\
\text { insufficiency, aortic stenosis } \\
\text { Mitral valve prolapse with mitral } \\
\text { insufficiency or valve thickening } \\
\text { Bicuspid aortic valve } \\
\text { Congenital non-cyanotic heart } \\
\text { diseases except for atrial septal } \\
\text { defect (cardiac condition without } \\
\text { risk) } \\
\text { Obstructive hypertrophic } \\
\text { cardiomyopathy (with murmur } \\
\text { on auscultation) }\end{array}$ \\
\hline
\end{tabular}


Table 2 Indications for infective endocarditis antibiotic prophylaxis in patients undergoing oral or dental procedures according to the group of cardiac conditions at risk

\begin{tabular}{lll}
\hline $\begin{array}{l}\text { Oral or dental } \\
\text { procedural risk }\end{array}$ & $\begin{array}{l}\text { Group A: cardiac } \\
\text { conditions conferring } \\
\text { high risk of IE }\end{array}$ & $\begin{array}{l}\text { Group B: Cardiac } \\
\text { conditions conferring } \\
\text { lower risk of IE }\end{array}$ \\
\hline $\begin{array}{l}\text { With risk } \\
\text { Without risk }\end{array}$ & $\begin{array}{l}\text { Recommended } \\
\text { Not recommended }\end{array}$ & $\begin{array}{l}\text { Optional } \\
\text { Not recommended }\end{array}$ \\
\hline
\end{tabular}

Table 3 Factors that may help in choosing whether antibiotic prophylaxis will be prescribed when prophylaxis is optional

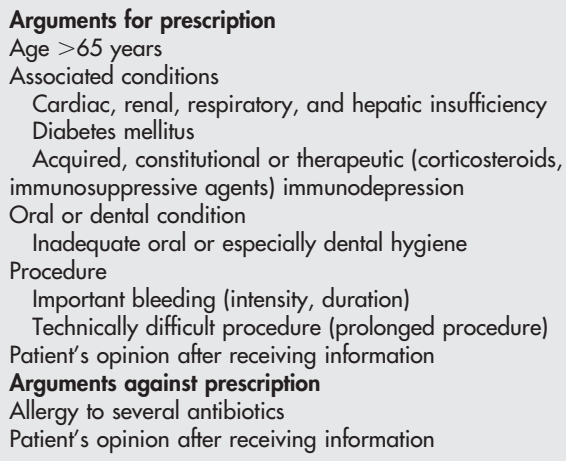

and trauma require extraction. Other procedures are described in the full text.

\section{Group B patients}

Antibiotic prophylaxis is optional.

Antibiotic prophylaxis must be chosen by health care professionals, taking into account the nature of the procedures and the patient's general condition. Table 3 lists factors that can influence this choice. Whatever the choice, it must be made after informing the patient and obtaining his or her
Table 4 Indications for antibiotic prophylaxis in patients with other than oral or dental procedures

\begin{tabular}{|c|c|c|}
\hline $\begin{array}{l}\text { Procedural } \\
\text { risk }\end{array}$ & $\begin{array}{l}\text { Group A: conditions } \\
\text { conferring high risk of IE }\end{array}$ & $\begin{array}{l}\text { Group B: conditions } \\
\text { conferring lower risk of IE }\end{array}$ \\
\hline Very high & Recommended & Recommended \\
\hline High & Recommended & Optional \\
\hline Low & Optional & Not recommended \\
\hline Negligible & Not recommended & Not recommended \\
\hline
\end{tabular}

consent to the proposed strategy. Each patient should be given a follow up leaflet where the proposed strategy has to be reported. Patients should know that in case of fever or symptoms, especially in the month following dental procedures, they must consult a physician as soon as possible before starting any drug and inform the physician of their dental history so that blood cultures can be made before initiating any antibiotic (fig 1 ).

Root treatment may be undertaken only under specific conditions. Implants, periodontal procedures, and some other procedures are contraindicated (see full text).

\section{For other cardiac conditions}

For other cardiac conditions, antibiotic prophylaxis is not recommended.

Before valve surgery, antibiotic prophylaxis is indicated as for group A patients. A complete radiological dental assessment must be made; only pulped teeth or teeth that have had a perfect endodontic treatment (more than a year before) without periodontal enlargement and with a healthy periodontium are kept. Pulpectomised teeth with incomplete endodontic treatment and teeth presenting with periodontal lesions and persisting roots and apex are extracted at least 15 days before cardiac surgery. In case of emergency surgery, dental care is given as soon as possible according to the context.

Indications according to the kind of procedure are described in addendum 2 of the full text.

\section{RECOMMENDATION 4: OTHER PROCEDURES AT RISK}

These recommendations are based on professional consensus, in the absence of scientific data, and cannot replace the

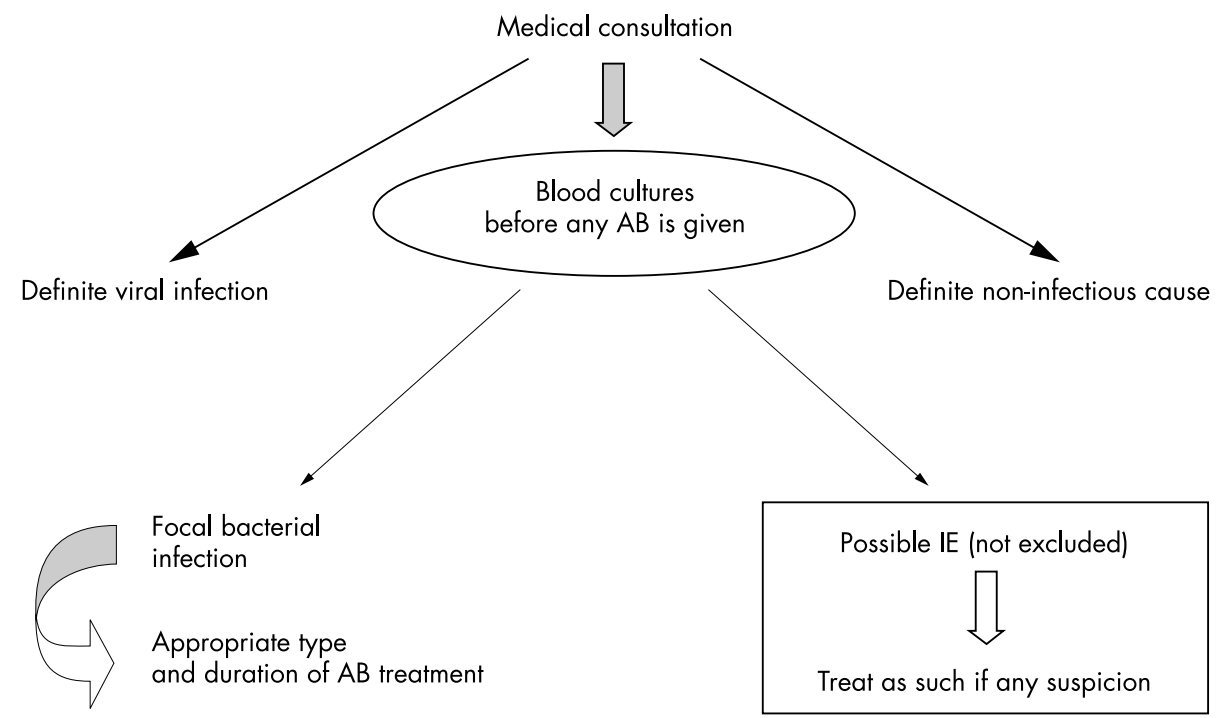

Figure 1 Treatment procedure for febrile patients with a cardiac condition conferring a lower risk of infective endocarditis (IE) (group B) $<3$ months after a risky procedure, particularly if no antibiotic prophylaxis was used. $A B$, antibiotic. 
Table 5 Antibiotic prophylaxis for IE in dental care and upper respiratory tract procedures: administration of antibiotics respecting contraindications and usual conditions of use and surveillance

\begin{tabular}{|c|c|c|c|}
\hline & Antibiotic & Dosage and route of administration & \\
\hline $\begin{array}{l}\text { Ambulatory care* } \\
\text { No allergy to } \beta \text { lactams } \\
\text { Allergy to } \beta \text { lactams } \\
\text { General anaesthesia§ } \\
\text { No allergy to } \beta \text { lactams } \\
\text { Allergy to } \beta \text { lactams }\end{array}$ & 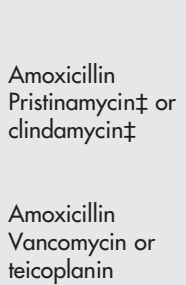 & $\begin{array}{l}\text { Single dose in the hour before the } \\
\text { procedure } \\
3 \mathrm{~g} \text { orally } \\
1 \mathrm{~g} \text { orally } \\
600 \mathrm{mg} \text { orally } \\
\text { Before (in the hour before the } \\
\text { procedure) } \\
2 \mathrm{~g} \text { iv (infusion } 30 \mathrm{~min} \text { ) } \\
1 \mathrm{~g} \text { iv (infusion } \geqslant 60 \mathrm{~min} \text { ) } \\
400 \mathrm{mg} \text { iv (bolus) }\end{array}$ & $\begin{array}{l}\text { After (6 hours later) } \\
1 \mathrm{~g} \text { orally } \\
\text { No second dose }\end{array}$ \\
\hline
\end{tabular}

*Oral paediatric dosages: amoxicillin $75 \mathrm{mg} / \mathrm{kg}$; clindamycin $15 \mathrm{mg} / \mathrm{kg}$; pristinamycin $25 \mathrm{mg} / \mathrm{kg}$; $† 2 \mathrm{~g}$ orally if the patient's weight is $<60 \mathrm{~kg}$; tthe respective percentage of streptococci strains with a decreased susceptibility to these two antibiotics must be taken into account for the choice; §paediatric dosages: amoxicillin $50 \mathrm{mg} / \mathrm{kg}$ intravenously (iv) before, $25 \mathrm{mg} / \mathrm{kg}$ orally 6 hours later; vancomycin $20 \mathrm{mg} / \mathrm{kg}$ (maximum $1 \mathrm{~g}$ ); teicoplanin: no official approval for antibiotic prophylaxis in children.

Table 6 Antibiotic prophylaxis for IE during urological and digestive procedures: Administration of antibiotics respecting contraindications and usual conditions of use and surveillance

\begin{tabular}{|c|c|c|c|}
\hline & \multirow[b]{2}{*}{ Antibiotic } & \multicolumn{2}{|l|}{ Dosage and route of administration } \\
\hline & & Before (in the hour before the procedure) & After (6 $\mathrm{h}$ hours later) \\
\hline $\begin{array}{l}\text { No allergy to } \beta \\
\text { lactams } \\
\text { Allergy to } \beta \\
\text { lactams }\end{array}$ & $\begin{array}{l}\text { Amoxicillin then } \\
\text { gentamicin } \\
\text { Vancomycin or } \\
\text { teicoplanin then } \\
\text { gentamicin }\end{array}$ & $\begin{array}{l}2 \mathrm{~g} \text { iv (infusion } 30 \mathrm{~min} \text { ) } \\
1.5 \mathrm{mg} / \mathrm{kg} \text { iv (infusion } 30 \mathrm{~min} \text { ) or im } \\
1 \mathrm{~g} \text { iv (infusion } \geqslant 60 \mathrm{~min} \text { ) } \\
400 \mathrm{mg} \text { iv (bolus) } \\
1.5 \mathrm{mg} / \mathrm{kg} \text { iv (infusion } 30 \mathrm{~min} \text { ) or im }\end{array}$ & $\begin{array}{l}1 \mathrm{~g} \text { orally } \\
\text { No second dose } \\
\text { No second dose }\end{array}$ \\
\hline
\end{tabular}

Paediatric dosage: amoxicillin $50 \mathrm{mg} / \mathrm{kg}$ iv before, $25 \mathrm{mg} / \mathrm{kg}$ orally 6 hours later; gentamicin $2 \mathrm{mg} / \mathrm{kg}$ (maximum $80 \mathrm{mg}$ ); vancomycin $20 \mathrm{mg} / \mathrm{kg}$ (maximum $1 \mathrm{~g}$ ); teicoplanin: no official approval for antibiotic prophylaxis in children.

im, intramuscularly.

If antibiotic prophylaxis concerns a procedure for which the microorganism is a staphylococcus, pristinamycin should be used unless contraindicated.

clinician's best judgment (table 4). They should not override recommendations concerning preoperative antibiotic prophylaxis of surgical procedures.

\section{RECOMMENDATION 5: ANTIBIOTIC PROPHYLAXIS PRESCRIPTION}

The working group considers that the evolution of the epidemiology of infective endocarditis in France is an argument to maintain the current mode of antibiotic prophylaxis administration.

Table 7 Propositions for the assessment and diffusion of recommendations

1. Identify the risk level related to a valve disease (specify group A or B) in the:

- echocardiography report

- clinical file

- IE prevention card

2. Provide a heart disease health care leaflet for patients with a cardiac condition conferring risk in groups $A$ and $B$

3 . Set up a cohort registry of patients with a cardiac condition at risk undergoing dental procedures

4. Establish a national registry of $\mathrm{IE}$, recording risky procedures and antibiotic use before the current episode

\section{General modes of antibiotic prophylaxis administration}

Generally, antibiotic prophylaxis is initiated in the hour before the procedure according to the mode described below (tables 5 and 6). Nevertheless, if problems possibly leading to a specific infectious risk arise during or immediately after a procedure without prior antibiotic prophylaxis (abundant bleeding, long and difficult procedures, etc), initiating antibiotic prophylaxis as soon as possible after the procedure may be indicated. This decision is to be taken by the professional in charge.

The modes of antibiotic prophylaxis administration do not apply if curative antibiotic treatment is indicated.

\section{PROPOSITIONS}

The working group makes the propositions listed in table 7 regarding the screening, follow up, and information of patients with cardiac conditions that confer risk.

\section{APPENDIX}

The revision of the March 1992 French consensus conference on the prophylaxis of infective endocarditis (Recommendations 2002) was supported by the Société de Pathologie Infectieuse de Langue Française (SPILF) with the collaboration of the Société Française de Cardiologie (SFC) and the participation of the following:

- Association Dentaire Française 
- Association pour l'Étude et la Prévention de l'Endocardite Infectieuse

- Association des Épidémiologistes de Langue Française

- Association Pédagogique Nationale pour l'Enseignement de la Thérapeutique

- Fédération Française de Cardiologie

- Société de Chirurgie Thoracique et Cardio-Vasculaire

- Société Française de Microbiologie

- Société Française de Parodontologie et d'Implantologie Orale

- Société de Stomatologie, de Chirurgie Maxillo-faciale et Chirurgie Plastique de la Face

- Association Française d'Urologie

- Société Francophone de Médecine Buccale et de Chirurgie Buccale

- Société Nationale Française de Gastro-Entérologie

- la Société Nationale Française de Médecine Interne

- UNAFORMEC
- Agence Nationale d'Accréditation et d'Évaluation en Santé (ANAES).

Reading committee:

- Collège National des Généralistes Enseignants

- Société de Formation Thérapeutique du Généraliste

- Société Française de Médecine Générale.

\section{Authors' affiliations}

N Danchin, Department of Cardiology, Hôpital Européen Georges Pompidou, Paris, France

X Duval, C Leport, Department of Infectious Diseases, Hôpital Bichat, Paris, France

Correspondence to: Professor Nicolas Danchin, Department of Cardiology, Hôpital Européen Georges Pompidou, 20 rue Leblanc, 75015 Paris, France; nicolas.danchin@egp.ap-hop-paris.fr

Accepted 11 March 2004

\section{IMAGES IN CARDIOLOGY}

\section{Sixteen row cardiac computed tomography in the diagnosis of arrhythmogenic right ventricular cardiomyopathy}

A rrhythmogenic right ventricular cardiomyopathy (ARVC) is a disorder of the heart muscle characterised pathologically by replacement of the right ventricular myocardium with fatty or fibrous fatty tissue. Recently, because of its excellent spatial and temporal resolution, 16 row multislice computed tomography (CT) has received much attention as a non-invasive method of diagnosing cardiac disorders. Its usefulness in the diagnosis of the ARVC has not been previously reported.

We present the case of a 33 year old woman with a history of palpitations. The ECG showed sinus rhythm and right bundle branch block. An atypical auricular flutter was reported. The echocardiogram showed discrete right ventricular dilatation and hypocontractile areas but not conclusive images of ARVC.
Cardiac 16 row multislice CT was performed and showed the enlarged myocardial trabeculae, particularly on the anterior and inferior walls, which explains the angiographic images of deep fissures. A scalloped appearance of the free wall of the right ventricle corresponds to the finding of localised akinetic or dyskinetic bulges seen at the apex, infundibulum, and inferior wall.
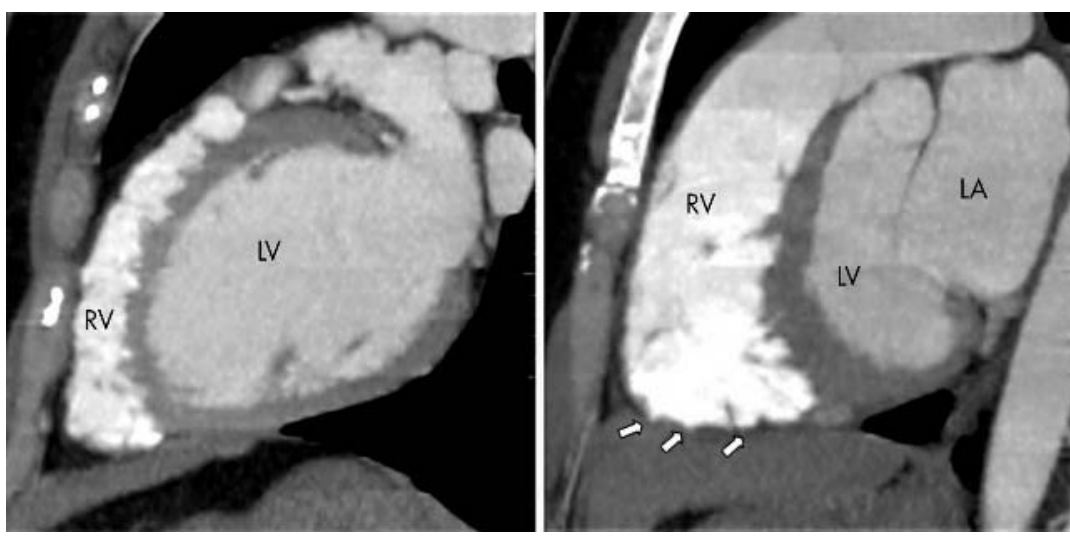

Left: Reformatted image in short axis scan showing enlarged myocardial trabeculae. Right: Reformatted image in short axis scan show bulging of the inferior wall (arrows), which is compatible with aneurysm formation and is pathognomonic for ARVC. LA, left atrium; LV, left ventricle; RV, right ventricle.

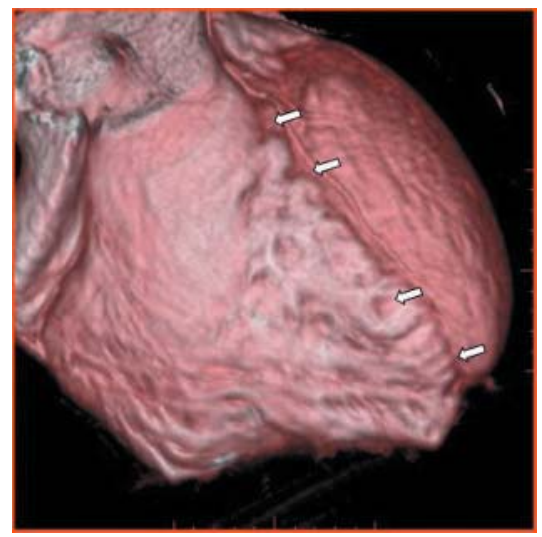

Slightly scalloped appearance of the right ventricle in volume rendering reconstruction. Arrows show slight bulging of the anterior wall of the right ventricle with ARVC. 